\title{
Pathologic Stage IVA Esophageal Squamous Cell Carcinoma AJCC v8
}

National Cancer Institute

\section{Source}

National Cancer Institute. Pathologic Stage IVA Esophageal Squamous Cell Carcinoma

A/CC v8. NCl Thesaurus. Code C133541.

Stage IVA includes: (T4a, N2, M0, Any G, Tumor location: Any); (T 4b, N0-2, M0, Any G, Tumor location: Any); (Any T, N3, M0, Any G, Tumor location: Any). T4a: Tumor invades the pleura, pericardium, azygos vein, diaphragm, or peritoneum. T4b: Tumor invades other adjacent structures, such as the aorta, vertebral body, or airway. N0: No regional lymph node metastasis. N1: T umor with metastasis in one or two regional lymph nodes. N2: T umor with metastasis in three to six regional lymph nodes. N3: T umor with metastasis in seven or more regional lymph nodes. M0: No distant metastasis. (AJCC 8th ed.) 